\title{
POTENSI +DALETHYNE TERHADAP EPITELISASI LUKA PADA KULIT TIKUS YANG DIINFEKSI BAKTERI MRSA
}

\author{
William Sayogo*¹, Agung Dwi Wahyu Widodo², Yoes Prijatna Dachlan ${ }^{3}$ \\ ${ }^{1,2,3}$ Sekolah Pascasarjana Universitas Airlangga; Kampus B. Jl. Airlangga No. 4-6, Surabaya \\ 60286, Telp. (031) 5041566 / Fax. (031) 5029856 \\ Program Studi S2 Imunologi, Sekolah Pascasarjana Universitas Airlangga, Surabaya \\ e-mail: *1. sayogowilliam@gmail.com, ${ }^{2}$ agungmd_imun@yahoo.com
}

\begin{abstract}
Abstrak
Proses penyembuhan luka merupakan bagian regenerasi jaringan kulit untuk memperbaiki kerusakan. Proses ini akan terhambat dengan adanya infeksi bakteri, terutama bakteri MRSA (Methicillin resistant Staphylococcus aureus) yang resisten terhadap antibiotik dan mampu membentuk lapisan biofilm. Penelitian ini bertujuan untuk mengetahui efek topikal +dalethyne terhadap epitelisasi pada proses penyembuhan luka terinfeksi MRSA di kulit tikus wistar. Tiga puluh enam ekor tikus Wistar, berumur 3 bulan, dibagi dalam 6 kelompok, kontrol negatif (didekapitasi hari keempat dan hari keenam), kontrol positif (didekapitasi hari keempat dan keenam), perlakuan (didekapitasi hari keempat dan hari keenam). Perlukaan pada kulit punggung dengan cara diinsisi menggunakan pisau sepanjang $2 \mathrm{~cm}$ dan kedalaman sampai subkutan. Luka pada kontrol positif diinfeksikan MRSA, kelompok perlakuan diinfeksikan MRSA dan diaplikasikan +dalethyne. Setelah didekapitasi masing-masing kelompok pada hari ke-4 dan ke-6, jaringan kulit difiksasi dan dibuat preparat dan diberi pewarnaan Hemaktosilin Eosin. Panjang epitel diukur menggunakan Optilab yang dipasang pada mikroskop cahaya. Data panjang epitel dianalisis dengan membandingkan jumlah rerata dan SD. Panjang epitel pada kelompok perlakuan lebih tinggi dibandingkan kontrol positif $\{(0,46 \pm 0,19) v s(0,21 \pm 0,16) ;(0,63 \pm 0,76) v s(0,42 \pm 0,301)$, sedang dibandingkan dengan kontrol negatif tidak jauh berbeda pada hari ke-4 dan ke-6 setelah perlukaan. Kesimpulan aplikasi topikal +dalethyne mempercepat epitelisasi pada proses penyembuhan luka kulit tikus yang terinfeksi MRSA.
\end{abstract}

Kata kunci: Penyembuhan luka, infeksi MRSA, +dalethyne, epitelisasi

\begin{abstract}
Wound healing is part of the regeneration of skin tissue from the damage. This will be hampered by the Methicillin resistant Staphylococcus aureus (MRSA) infection. This study aims to determine the effect of +dalethyne against epithelialization in wound healing of the skin MRSA-infected rats. Thirty six Wistar rats, 3 months old, are divided into 6 groups, 2 groups of negative control, 2 groups of positive control, 2 groups of treatment group (All are sacrificed on the fourth day and sixth day). Injury to the back skin of rats by a knife along the incised $2 \mathrm{~cm}$ and depth to subcutaneous. Wound of positive control groups infected by MRSA, wound in the treatment groups also infected MRSA and then applied topically +dalethyne. Each groups are sacrificed on day 4 and 6, the skin tissue is fixed, made histological preparations, stained with $H E$. The measurement of the epithelial length using Optilab mounted on a light microscope. The data are analyzed by comparing the mean and SD. The epithelial length in the treatment group was higher than the positive control $\{(0,46 \pm 0,19) v s(0,21 \pm 0,16) ;(0,63 \pm 0,76) v s(0,42 \pm 0,301)$, being compared with the negative control is not much different. Conclusion: Topical +dalethyne accelerates epithelialization in wound healing of the skin MRSA-infected rat.
\end{abstract}

Keywords: Wound healing, MRSA infection, +dalethyne, epithelialization 


\section{PENDAHULUAN}

Infeksi nosokomial sampai sekarang masih menjadi masalah serius terutama pada pasien yang harus menjalani perawatan di rumah sakit untuk jangka waktu yang lama. Beberapa bakteri penyebab infeksi nosokomial resisten terhadap satu atau beberapa antibiotik. Ini menyebabkan kondisi pasien yang rawat inap menjadi lebih buruk bahkan bisa menyebabkan kematian dan tentu saja biaya yang dikeluarkan pasien menjadi lebih besar. Tentu ini merugikan masyarakat pengguna pelayanan kesehatan seperti di rumah sakit. Salah satu indikator yang dipakai untuk menilai kinerja rumah sakit adalah infeksi nosokomial, yang merupakan indikator mutu pelayanan rumah sakit. Menurut keputusan menteri kesehatan (kepmenkes) tahun 2002 yang termasuk infeksi nosokomial adalah infeksi saluran kemih, infeksi luka operasi, pneumonia nosokomial, bakteriemia nosokomial, infeksi phlebitis serta infeksi lainnya. Kejadian infeksi nosokomial di RSUD Setjonegoro kabupaten Wonosobo menunjukkan peningkatan dari tahun 20102011 (0,37\% menjadi $1,48 \%$ kasus). Prevalensi angka kejadian infeksi nosokomial di RSUD Setjonegoro pada semester II tahun 2009 (2,67), semester I dan II tahun 2010 (3,12 dan 4,36), serta semester I dan II tahun 2011 (9,68 dan 19,71) per 1000 pasien rawat inap (Nugraheni et al, 2012). Kasus infeksi nosokomial di Rumah Sakit Bhayangkara Surabaya terbanyak adalah phlebitis karena tindakan pemasangan infus. Dari tanggal 1 sampai 31 Mei 2013, di ruang rawat inap Rumah Sakit Bhayangkara Surabaya ditemukan kejadian phlebitis dari pasien yang telah dipasang infus terdapat 27 pasien yang mengalami phlebitis dari 145 pasien yang terpasang infus atau sekitar 18,6\%, yang sudah menampakkan adanya tanda-tanda phlebitis seperti bengkak di sekitar tusukan jarum infus, kemerahan, dan nyeri sepanjang vena (Fitriyanti, 2015). Data terakhir dari Centers for Disease Control and Prevention menunjukkan $60 \%$ tempat pelayanan kesehatan di Amerika Serikat terjadi infeksi nosokomial yang disebabkan MRSA (methicillin-resistant Staphylococcus aureus). MRSA tipe CA-MRSA ( community acquired MRSA) saat ini menjadi endemis pada beberapa rumah sakit di Amerika Serikat (Palavecino, 2014)

Infeksi oleh bakteri menghambat proses penyembuhan luka pada kulit pasien yang menjalani perawatan di rumah sakit, seperti pasien yang mendapat tindakan pembedahan, pemasangan protesis tulang, pemasangan kateter urin, pemasangan infus dalam waktu lama, luka gangren dan dekubitus pada pasien penyakit metabolik kronik dengan atau tanpa mengalami komplikasi atau pada pasien dengan defisiensi imun. Beberapa mikroba yang menyebabkan infeksi nosokomial pada kulit antara lain Staphylococcus aureus, Streptococcus pyogenes, Acinetobacter sp., Pseudomonas sp. Di penelitian ini dipilih bakteri Staphylococcus aureus sebagai salah satu penyebab infeksi nosokomial pada kulit, dengan alasan bakteri ini biasanya merupakan bakteri yang sering ditemukan pada suatu keadaan infeksi yang berat atau kondisi pasien yang mengalami defisiensi imun atau infeksi gabungan dengan bakteri lainnya, bakteri ini juga dapat menyebabkan infeksi yang berat pada kulit (Tortora, 2016)

Methicillin resistant Staphylococcus aureus (MRSA) termasuk bakteri yang mampu menghasilkan biofilm, toksin dan superantigen sehingga dapat menghindari sistem imun dalam tubuh dan juga mampu melindungi diri dari perusakan oleh antibiotik dengan transfer staphylococcal cassette chromosome mec (SSCmec) yang menghasilkan pelindung terhadap antibiotik yang mempunyai struktur methicillin. Staphylococcus aureus tipe ini bila menginfeksi pada kulit yang tidak utuh (seperti mengalami luka) akan memperberat tingkat kesakitan (Murray et al, 2016)

Luka pada kulit dapat terjadi oleh berbagai sebab antara lain luka karena trauma (mekanis, kimia, termal, elektrik) atau juga bisa dikarenakan penyumbatan pembuluh darah (seperti pada Buerger disease). Luka menyebabkan hilangnya struktur kulit bisa hanya terbatas pada epidermis atau bisa sampai dermis bahkan juga bisa sampai 
mengenai otot. Bila luka sampai mengenai struktur dermis atau otot akan disertai perdarahan karena pembuluh darah juga terkena. Luka menjadi port d'entry bagi mikroorganisme untuk masuk ke dalam tubuh, menjadikan luka menjadi tidak steril. Mikroorganisme patogen yang masuk melalui kulit yang tidak intak dapat menyebabkan infeksi, dimana infeksi tersebut bisa bersifat lokal, menyebar sampai jaringan di bawah kulit bahkan dapat menyebar secara sistemik ke organ lain tergantung dari patogenitas dari mikroorganisme tersebut. Infeksi tersebut memicu respon imunitas tubuh untuk mengeradikasi kuman tersebut. Proses imun tersebut bisa bersifat non spesifik (innate) dan bisa juga sampai bersifat spesifik (acquired) (Abbas, 2015)

Ketika trauma terjadi dan merusak struktur kulit oleh berbagai sebab terjadilah keradangan atau inflamasi sebagai aksi pertahanan tubuh yang pertama dalam mempertahankan jaringan kulit agar tidak terjadi kerusakan yang meluas. Pada saat proses keradangan atau inflamasi tersebut berlangsung, terjadilah infiltrasi sel-sel radang seperti PMN (polimorfonuclear), makrofag dan limfosit yang bertujuan untuk menghancurkan jejas dan mikroorganisme patogen yang masuk ke daerah luka. PMN dan makrofag akan memfagosit kuman yang masuk melalui luka tersebut dan menghancurkan kuman tersebut dengan menghasilkan radikal bebas. Sedangkan limfosit diaktifkan melalui reseptor pengenalan patogen yang diekspresikan oleh sel dendritik. Limfosit yang teraktifasi akan menghasilkan sitokin pro inflamasi (TNF- $\alpha$, IL-1, IL-6, IL-8) (Modlin et al, 2008)

Epitelisasi merupakan salah satu mekanisme dasar penyembuhan luka. Tiga jaringan pokok yang berperan pada proses penyembuhan yaitu jaringan ikat, pembuluh darah dan epitel. Proses epitelisasi berlangsung kompleks yang melibatkan sel epitel berupa perubahan struktur internal sel epitel meliputi migrasi, proliferasi dan diferensiasi. Seringkali pada fase penyembuhan tersebut terjadi overlapping waktu, fisiologi dan tipe sel. Hal tersebut tergantung pada etiologi penyebab luka, ada tidaknya infeksi, adanya obat atau tindakan yang mengintervensi (Han, 2016)

Adanya masalah resistensi bakteri terhadap banyak antibiotik, menyebabkan angka kematian dikarenakan infeksi MRSA semakin tinggi. Diperlukan obat lain yang juga mempunyai efektifitas untuk meeradikasi kuman yang resisten terhadap banyak antibiotik menjadi tantangan saat ini, dengan harapan angka kematian dikarenakan infeksi MRSA dapat ditekan. +dalethyne merupakan senyawa aktif baru yang diekstrak secara ozonisasi, terdiri dari kombinasi senyawa yaitu: minyak esensial (aldehyde), asam lemak (stearat, oleat, linoleat, palmitat), iodine dan peroksida. +dalethyne tersebut membentuk antimicrobial agent yang mampu membunuh bakteri juga mampu merangsang pembentukan jaringan baru pada kulit yang mengalami luka.

\section{TINJAUAN PUSTAKA \\ 2.1 Struktur dan Fungsi Kulit}

Kulit merupakan organ tubuh terluas, berat total berkisar 2,7-3,6 kg dan menerima sepertiga dari volume darah tubuh, ketebalan kulit bervariasi antara $0,5-6,0 \mathrm{~mm}$, terdiri dari sel - sel dan matriks ekstraselular. Struktur kulit terdiri dari 3 lapisan, epidermis merupakan lapisan terluar kulit dan tipis, dermis merupakan lapisan tebal dan terletak di dalam, lapisan di bawah dermis terdapat jaringan lemak subkutan (hipodermis). Jaringan hipodermis merupakan jaringan ikat longgar yang melekat di bawah dermis (Chu, 2008)

Kulit manusia mempunyai banyak fungsi yang penting terutama sebagai pertahanan garis depan, melindungi tubuh dari berbagai elemen yang berasal dari lingkungan luar tubuh. Jika terjadi luka pada kulit, integritas pertahanan kulit menjadi terganggu dan menjadi tempat masuk berbagai mikroorganisme seperti bakteri dan virus. Kulit juga dapat menjadi faktor penting dalam kesehatan mental dan kondisi sosial manusia (Han, 2016) 


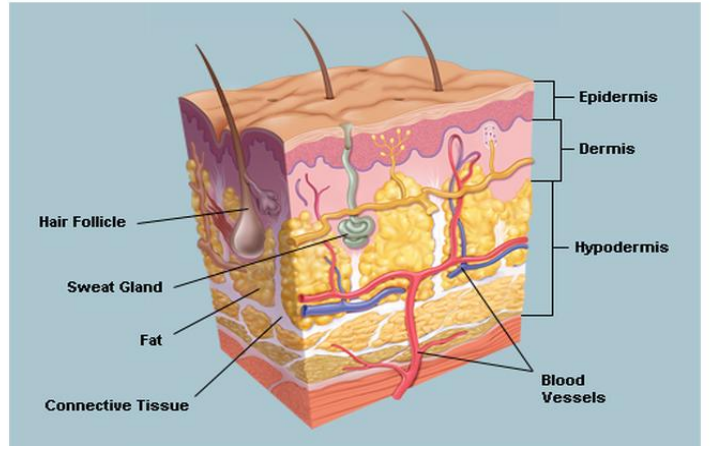

Gambar 1. Struktur kulit

Fungsi Epidermis sebagai pertahanan tubuh terluar terhadap lingkungan luar tubuh. Suasana asam pada kulit melindungi kulit dari mikroorganisme. Lapisan keratin yang keras melindungi tubuh dari invasi mikroorganisme dan infeksi juga menjaga kelembaban. Sel Langerhans membentuk reseptor pengenalan baik terhadap mikroorganisme, virus bahkan senyawa asing yang selanjutnya mengaktifkan sistem imunitas. Kemampuan tubuh mempertahankan kadar air penting untuk menjaga kesehatan kulit. Jumlah dan distribusi pigmen melanin yang memberikan keragaman warna pada kulit manusia. Vitamin D disintesis di epidermis dengan bantuan sinar ultraviolet, sintesis ini dilakukan oleh keratinosit yang terletak pada stratum basale dan stratum spinosum dari epidermis (Flanagan, 2013)

Dermis merupakan "rumah" dari komponen tambahan dari epidermis. Di dermis terdapat sel - sel imun yang berfungsi melawan infeksi yang masuk ke dalam kulit. Dermis menyediakan suplai darah, nutrisi dan oksigen pada dirinya sendiri dan juga epidermis. Dermis juga mempunyai fungsi pengaturan suhu kulit melalui pembuluh darah superfisial dan reseptor saraf berfungsi untuk sensasi rasa raba (Han, 2016)

Jaringan hipodermis atau subkutan merupakan lapisan yang terdiri dari lemak dan jaringan ikat yang kaya akan pembuluh darah dan saraf. Lapisan ini penting dalam pengaturan suhu kulit dan tubuh (Han, 2016)

\subsection{Luka dan Proses Penyembuhan}

Luka adalah suatu kondisi dimana adanya kerusakan pada struktur normal kulit dengan kedalaman dan tingkat berat ringan dari kondisi luka yang berbeda. Luka tidak hanya berbentuk goresan atau robekan pada lapisan kulit saja, tetapi bisa sampai jaringan di bawah kulit. Luka ada yang berbentuk luka terbuka, ada yang berbentuk luka tertutup. Luka terbuka misalnya luka insisi, laserasi, abrasi, luka tusuk, luka tembus. Luka tertutup berupa luka memar karena benda tumpul, lebam, luka dengan jaringan di bawah kulit rusak tetapi jaringan epidermis dan dermis masih utuh. Kedalaman luka beragam, kalau hanya terbatas pada epidermis disebut luka superfisial, bila meliputi sebagian lapisan dermis disebut luka partial - thickness. Luka full - thickness bila luka meliputi seluruh lapisan epidermis dan dermis bahkan bisa mengenai jaringan di bawah kulit seperti jaringan subkutan, fasia dan otot. Luka akut adalah luka yang proses penyembuhannya dapat diperkirakan waktunya antara $7-14$ hari (Han, 2016)

Proses penyembuhan luka ada 4 fase yaitu: fase hemostasis, fase inflamasi, fase proliferasi, fase remodelling atau penyusunan kembali struktur kulit. Pada gambar $2 \mathrm{j}$ tampak perkiraan waktu mulai serta lama dari masingmasing fase pada proses penyembuhan luka yang fungsional (tidak ada komplikasi atau infeksi) (Han, 2016)

\subsubsection{Fase Hemostasis}

Hemostasis terjadi segera setelah terjadi trauma, untuk menghentikan pendarahan dengan cara pembuluh darah yang terbuka mengalami vasokonstriksi dan platelet teraktifasi lalu saling menempel dan beragregasi di daerah luka. Platelet diaktifasi oleh kolagen ekstraselular (tipe I). Begitu platelet berinteraksi dengan kolagen, platelet akan melepaskan mediator (faktor pertumbuhan dan cyclic $A M P$ ) dan glikoprotein, yang memberi sinyal kepada platelet untuk menjadi lebih lengket dan berakumulasi. Granul alfa platelet melepaskan 
glikoprotein berupa fibrinogen, fibronektin, thrombospondin dan faktor von Willebrand. Saat terjadi agregasi platelet, faktor pembekuan darah dilepaskan menyebabkan fibrin mengendap di daerah luka (Kumar et al, 2015)

\subsubsection{Fase Inflamasi}

Fase ini terjadi 24 jam setelah terjadi trauma pada kulit dan bisa berlangsung sampai 2 minggu tergantung apakah ada infeksi yang memperpanjang fase ini. Sel mast melepaskan granul yang berisi enzim, histamine dan amin aktif lainnya yang menimbulkan tanda-tanda inflamasi yaitu rubor (kemerahan), calor (panas), tumor (bengkak), pain (nyeri) di daerah sekeliling luka. Neutrofil, monosit dan makrofag merupakan sel-sel utama pada fase ini. Sel-sel ini berfungsi membersihkan infeksi pada luka dan debris dan melepaskan mediator-mediator terlarut seperti sitokin pro inflamasi (TNF- $\alpha$, IL-1, IL-6, dan IL-8), dan faktor pertumbuhan (seperti PDGF, TGF- $\beta$, TGF- $\alpha$, IGF-1 dan FGF) yang terlibat dalam pengerahan dan pengaktifan fibroblast dan sel epitel untuk persiapan fase berikutnya dari proses penyembuhan luka (Koh et al, 2013)

\subsubsection{Fase Proliferasi}

Fibroblas bermigrasi ke luka sebagai respon terhadap mediator-mediator larut yang dilepaskan platelet dan makrofag. Migrasi dari fibroblas menuju ke matriks ekstraselular sangat bergantung pada pengenalan dan interaksi fibroblast dengan komponenkomponen spesifik dari matriks. Pada kondisi dermis normal fibroblas tidak aktif dan tidak terdistribusi, namun pada matriks di area luka dan pada jaringan granulasi, fibroblas menjadi aktif dan bertambah banyak. Fibroblas berikatan dengan komponen-komponen matriks seperti fibronektin, vitronektin, dan fibrin melalui reseptor integrin dari

fibroblas. Reseptor integrin melekat pada rangkaian asam amino spesifik (R-G-D atau asam arginin-glisin-aspartat) atau pada sisi ikatan dari komponen matriks. Ketika salah satu sisi fibroblas berikatan dengan komponen matriks, sel memperluas tonjolan sitoplasmanya untuk mencari sisi ikatan lainnya. Begitu menemukan sisi ikatan baru, sisi ikatan sebelumnya dilepaskan (oleh aktifitas protease lokal) dan sel menggunakan jaringan sitoskeleton serabut aktin untuk bergerak maju. Fibroblas mensekresikan enzim proteolitik untuk memfasilitasi pergerakan fibroblas menuju matriks. Enzim yang disekresikan meliputi tiga jenis MMP antara lain kolagenase (MMP-1), gelatinase (MMP-2 dan MMP-9) yang menghancurkan senyawa gelatin, stromelisin (MMP-3) yang mempunyai beberapa senyawa protein pada ECM (extracellular matrix) (Han, 2016)

\subsubsection{Fase Remodelling}

Remodeling merupakan fase terakhir dari proses penyembuhan luka yang terjadi setelah jaringan granulasi menjadi jaringan parut dan kekuatan elastisitas kulit meningkat. Pematangan jaringan granulasi melibatkan pengurangan jumlah kapiler dengan cara menyatu dengan pembuluh darah besar dan penurunan kadar glycosaminoglycan (GAG), air yang terikat pada GAG dan proteoglycan. Kepadatan sel dan aktifitas metabolisme menurun pada jaringan granulasi yang mengalami pematangan. Perubahan juga terjadi pada tipe, jumlah dan penyusunan kolagen, yang memperkuat elastisitas. Pada awalnya kolagen tipe III disintesis dalam jumlah banyak, selanjutnya digantikan kolagen tipe I, didominasi kolagen saraf di kulit. Kekuatan elastisitas epitel baru pada luka hanya $25 \%$ dibandingkan jaringan normal. Perbaikan jaringan kulit yang mengalami luka tidak akan pernah sekuat jaringan kulit normal yang tidak pernah mengalami luka (Han, 2016)

\subsection{Epitelisasi}

Proses epitelisasi merupakan proses yang meliputi perlekatan sel epitel dan terjadi perubahan struktur epitel selanjutnya bermigrasi, berproliferasi dan berdiferensiasi. Jaringan epidermis yang dewasa dan utuh terdiri dari lima lapisan seperti yang telah dijelaskan sebelumnya, sel-sel epitelnya 
berdiferensiasi dimulai dari keratinosit pada stratum basalis epidermis berbatasan dengan dermis yang berbentuk kuboid. Hanya sel-sel epitel stratum basalis yang mampu berproliferasi, selanjutnya melekat baik dengan sel-sel sekitar dan membran basalis melalui bantuan penghubung interselular yaitu desmosome (untuk perlekatan antar sel) dan hemidesmosomes (untuk perlekatan epitel dengan membran basalis). Faktor-faktor pertumbuhan (EGF, keratinocyte growth factor / KGF, TGF- $\alpha$ ) yang dilepaskan berikatan dengan reseptor masing-masing faktor pertumbuhan pada sel epitel dan memicu terjadinya migrasi dan proliferasi. Ikatan faktor pertumbuhan dengan reseptor memicu desmosome dan hemidesmosome larut sehingga sel dapat bermigrasi. Reseptor integrin terekspresi dan sel epitel basalis yang berbentuk kuboid berubah menjadi pipih dan bermigrasi membentuk lapisan tipis diatas jaringan granulasi baru, mengikuti panjang dari serabut kolagen (Li et al, 2005)

Proliferasi sel epitel basalis pada daerah sekitar luka menyediakan sel baru pada lapisan sel epitel diatas jaringan granulasi. Sel-sel epitel pada lapisan tersebut membentuk dan mensekresikan enzim proteolitik (MMP) yang memungkinkan sel berpenetrasi ke scar, permukaan nekrosis, atau eschar. Peranan MMP membentuk kembali ECM, migrasi sel, aktifasi faktor mitogenik. Migrasi sel terus berlanjut sampai sel epitel bertemu dengan sel tambahan lainnya membentuk lapisan yang menyatu. Begitu pertemuan terjadi, seluruh lapisan epitel dalam keadaan berproliferasi dan lapisan epidermis yang berlapis-lapis terbentuk dan matang untuk memperbaiki fungsi pertahanan kulit. TGF- $\beta$ merupakan salah satu faktor pertumbuhan yang mempercepat pematangan (perubahan dan keratinisasi) lapisan epidermis. Desmosome dan hemidesmosome intersellular menempel pada membran basalis yang baru. Epitelisasi menjadi penanda klinis dari penyembuhan luka tetapi bukan akhir proses penyembuhan (Han, 2016)

\subsection{Methicillin-resistant Staphylococcus aureus (MRSA)}

\subsubsection{Morfologi Staphylococcus aureus}

Bakteri S. aureus merupakan organisme bersel tunggal yang disebut prokaryotes. Bakteri ini berbentuk kokus (bulat) yang berkelompok (gambar 2d), struktur sitoplasmanya terdapat inti yang disebut nukleoid, kromosom dari bakteri ini merupakan DNA berserat ganda, ekstra kromosomal dan tidak ada nukleosom (plasmid), ribosom 70s dan tersusun dari subunit 30s dan 50s. Membran sitoplasma mempunyai struktur lemak (kolesterol) dua lapis. Bakteri ini mempunyai kapsul yang tersusun dari polisakarida, pili yang berfungsi untuk perlekatan, fimbrae dan flagella yang berfungsi untuk pergerakan dari bakteri (Murray et al, 2016)

Dinding sel bakteri merupakan suatu komplek, strukturnya kurang elastis, dan mempengaruhi bentuk sel. Fungsi utama dinding sel untuk melindungi sel bakteri dari perbedaan tekanan intraselular yang lebih besar dari ekstraselular yang berisiko sel tersebut akan ruptur (pecah). Secara klinis dinding sel penting karena berkontribusi pada kemampuan bakteri untuk menyebabkan penyakit, bagian perlekatan dengan reseptor APC (antigen precenting cell), juga menjadi tempat kerja dari antibiotik. Dinding sel bakteri S. aureus terdiri dari makromolekul peptidoglycan, teichoic acid dan lipoteichoic acid (Tortora et al, 2016) 


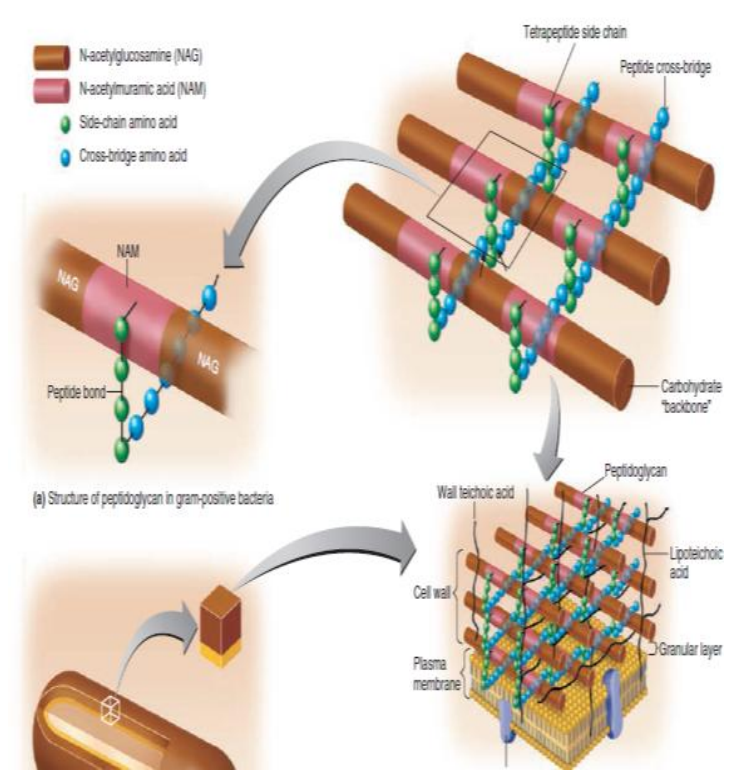

Gambar 2. Struktur dinding sel S.aureus

\subsubsection{Patogenesis Staphylococcus aureus}

Dua faktor penentu yang diduga sebagai faktor virulensi bakteri $S$. aureus yaitu gen ica yang menyandi pembentukan poly- $N$ acetylglucosamine/polysaccharide intercellular adhesion (PNAG / PIA) serta penyisipan gen IS256. IS256 berperan dalam adaptasi genetik pada saat infeksi, dengan cara menyisip pada lokus ica atau pada agr. Penyisipan pada ica akan meningkatkan pembentukan PNAG / PIA, sedang penyisipan pada agr akan menghambat fungsi regulasi pembentukan biofilm sehingga biofilm terbentuk semakin tebal. Kedua faktor virulensi ini membantu $S$. aureus untuk berkolonisasi baik yang komensal maupun yang menimbulkan infeksi (Sunhyo et al, 2014)

Peranan PNAG / PIA, PGA, dan protease ScpA melindungi bakteri terhadap protein anti mikroba yang dihasilkan pertahanan tubuh non spesifik (innate). Perlekatan interselular oleh PIA dan protein biofilm merupakan hal yang penting bagi bakteri terhadap stress mekanis pada lingkungan kulit. PGA berperan pada toleransi osmotik yang merupakan fungsi asli dari polimer ini pada $S$. aureus non infeksius. Perbedaan antara molekul protein permukaan surface components recognizing adhesive matrix molecules (MSCRAMMs) antara galur yang komensal dengan yang infeksius masih belum ada data yang jelas dan pasti. Karena faktor virulensi ini $S$. aureus secara klinis dapat menyebabkan infeksi kulit bergantung pada frekuensi kontaminasi oleh bakteri, mekanisme bakteri untuk melekat pada kulit manusia dan kemampuan bakteri menghindari sistem imun yang membantu bakteri untuk berkolonisasi dan bila dalam jumlah besar populasi bakteri tersebut dapat menimbulkan infeksi (Murray et al, 2016)

$S$. aureus menghasilkan beberapa toksin yaitu eksotoksin (5 toksin sitolitik, 2 toksin eksfoliatif, enterotoksin dan toxin shock syndrome toxin-1/TSST-1) dan endotoksin. Toksin eksfoliatif A, enterotoksin dan TSST-1 termasuk kelas polipeptida yang disebut superantigen (Murray et al, 2016)

Methicillin-resistant S

aureus mempunyai gen yang berperan dalam resisten antibiotik tertentu terutama resisten terhadap methicillin yang sering menjadi pilihan pertama antibiotik untuk infeksi stafilokokus. Gen yang menyandi resisten terhadap methicillin pada mobile genetic elements (MGEs) diberi nama staphylococcal cassette chromosome mec (SCCmec), yang mengandung gen mecA yang menyandi protein yang berikatan dengan penicillin / $\beta$ lactam, PBP2a (penicillin-binding protein $2 \mathrm{a}$ ). $\mathrm{PBP} 2 \mathrm{a}$ merupakan enzim pada membran bakteri yang mengkatalisa reaksi transpeptidasi yang penting untuk ikatan silang pada rantai peptidoglikan. Oleh karena PBP2a mempunyai afinitas yang rendah untuk semua antibiotik $\beta$ lactam, membuat stafilokokus mampu bertahan pada paparan dosis tinggi dari antibiotik golongan ini. Pada $S$. aureus ada 10 struktur SCCmec yang sudah teridentifikasi salah satunya SCCmec tipe IV. Pada S. aureus yang resisten metichillin ternyata juga ditemukan resisten terhadap antibiotik lain seperti rifampicin, flouroquinolone, gentamisin, tetracycline, chloramphenicol, erythromycin, clindamycin dan sulfonamide (Ito et al, 2014) 
2.5 Sistem Imun Kulit terhadap Infeksi MRSA

\subsubsection{Sistem Imun Non Spesifik}

Infeksi dimulai ketika patogen berhasil menembus pembatas anatomis dari inang. Beberapa mekanisme sistem imun non spesifik mulai diaktifkan meliputi beberapa kelompok molekul terlarut baik yang ada di cairan ekstraselular, darah, dan yang disekresikan sel epitel. Molekul terlarut antara lain enzim antimikroba seperti lysozyme untuk mencerna dinding sel bakteri; peptida antimikroba seperti defensin untuk melisiskan membran sel bakteri; sistem protein plasma yang dikenal sebagai sistem komplemen untuk melisiskan sel bakteri. Fagositosis dalam sistem imun non spesifik oleh sel seperti neutrofil dan makrofag. Bila fagositosis gagal membunuh bakteri, sel imun non spesifik diaktifkan oleh pattern recognition receptors (PRRs) yang mengenali molekul yang disebut pathogen-associated molecular patterns (PAMPs) yang merupakan ciri khas dari mikroba. Sel-sel pada sistem imun non spesifik yang teraktifasi melibatkan berbagai mekanisme efektor untuk menghilangkan infeksi. Bila infeksi masih mampu menembus pertahanan non spesifik maka mekanisme pertahanan melibatkan respon imun spesifik yang akan menghancurkan patogen secara spesifik dan membentuk sel-sel memori jangka panjang (Murphy, 2017)

\subsubsection{Sistem Imun Spesifik}

APC (antigen precenting cell) yang diinduksi oleh fagositosis $S$. aureus dan stimulasi TLR oleh komponen dinding sel $S$. aureus mengekspresikan MHC kelas II. MHC kelas II akan berikatan dengan TCR ( $T$ cell receptor) $\mathrm{CD}^{+}$. Sel $\mathrm{T}$ helper (sel Th) $\mathrm{CD} 4^{+}$ berdiferensiasi menjadi Th17 yang menghasilkan sitokin IL-17 dan IL-22. Sitokin IL-17 menstimulasi kemokin, sitokin lainnya (IL-1, IL-6, TNF, CSF/colony stimulating factor) yang meningkatkan produksi dan merekrut neutrofil selain itu juga menstimulasi produksi peptida anti mikroba (AMP). Sedang IL-22 berfungsi meningkatkan fungsi barrier dan menstimulasi produksi AMP. Sel APC juga menghasilkan sitokin IL-1 dan IL-6 yang bergabung dengan faktor pertumbuhan TGF- $\beta$ (transforming growth factor- $\beta$ ) mengaktifkan faktor transkripsi STAT3 dan ROR $\gamma \mathrm{T}$ yang menstimulasi diferensiasi dari sel $\mathrm{T} \mathrm{CD}^{+}$ menjadi Th17. Pada gambar 3 tampak adanya kolaborasi antara sistem imun non spesifik dan spesifik terhadap infeksi bakteri pada kulit (Ranzato, 2011)

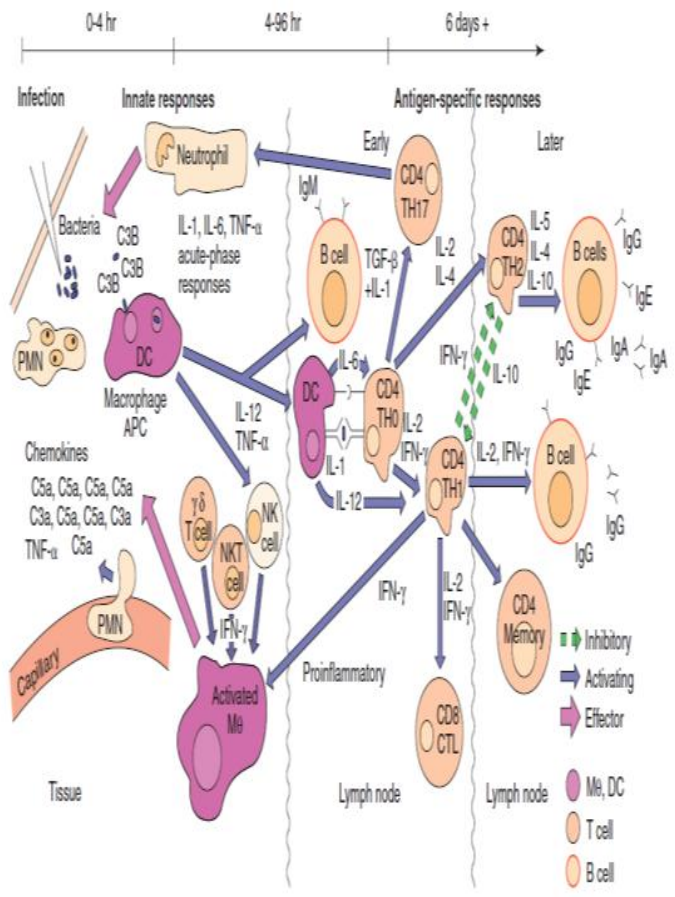

Gambar 3. Respon imun terhadap infeksi MRSA pada luka di kulit

2.6 Komponen Senyawa +dalethyne dan Fungsi Dalam Proses Penyembuhan Luka yang Terinfeksi Bakteri MRSA

+dalethyne senyawa yang berasal dari olive oil yang diozonisasi, pertama diperkenalkan di India pada tahun 2015 oleh suatu perusahaan yang bergerak di bidang pembuatan produk perawatan kulit berbasis dari tanaman. Proses ozonisasi melalui sistem injeksi ozon dengan menggunakan generator ozon plasma dingin (Edward, 2009)

Hasil pengujian yang dilakukan Unit Layanan Pengujian Fakultas Farmasi Universitas Airlangga diperoleh penyusun senyawa +dalethyne yaitu asam lemak (asam 
lemak oleat, asam lemak palmitat, asam lemak stearat, asam lemak linoleat), minyak essensial (golongan aldehyde), iodine dan peroksida.

Fungsi dari asam lemak tidak jenuh (unsaturated) mempunyai aktifitas anti bakteri yang sangat baik terhadap bakteri MRSA. Asam lemak tidak jenuh menghambat aktifitas enzim dalam sel bakteri, menghambat pengambilan nutrisi oleh bakteri, pembentukan peroksidasi dan auto oksidasi yang langsung berefek melisiskan sel bakteri.

Minyak esensial mempunyai aktifitas anti bakteri juga. Mekanismenya yaitu berefek pada dinding sel dan struktur membran bakteri, perubahan homeostasis $\mathrm{pH}$ di dalam sel bakteri, ekspresi chaperone dan protein permukaan sel yang berlebihan. Minyak esensial meningkatkan permeabilitas dari sel bakteri yang mengakibatkan hilangnya bahan penting dalam sel (berakibat trauma pada struktur sel). Minyak esensial menyebabkan influk proton yang menyebabkan kadar proton melebihi kapasitas penyangga sitoplasma, penurunan $\mathrm{pH}$, gangguan pada fungsi penting sel. Minyak esensial menyebabkan juga ekspresi berlebihan protein chaperone (DnaK, GroEL, HtpG dan Trigger factor Tf) dan protein permukaan sel (OmpX dan OmpA) yang menganggu jalur metabolik sel bakteri. Minyak esensial sangat efektif untuk menghambat pembentukan biofilm oleh bakteri MRSA melalui mekanisme quorum sensing yang menghambat pembentukan dan sekresi molekul sinyal yang penting dalam pembentukan biofilm. Pada bakteri MRSA yang resisten banyak obat, ternyata masih sensitif dengan minyak esensial (Faleiro et al, 2014)

Iodine dan peroksida merupakan antiseptik topikal yang mempunyai efek membunuh, menghambat atau mengurangi jumlah bakteri pada luka. Antiseptik ini mempunyai aktifitas antimikroba spektrum luas (Atiyeh, et al, 2009)

\section{METODE PENELITIAN}

Jenis penelitian merupakan penelitian eksperimental murni pada laboratorium (True Experimental) karena penelitian ini diberikan intervensi dengan semua variabel luar yang mempengaruhi dikendalikan, penelitian ini menggunakan rancangan penelitian Post Test Only Control Group Design. Obyek Penelitian adalah tikus Rattus norvegicus strain Wistar berumur sekitar 3 bulan dengan berat badan 200-250 gram. Kelompok obyek penelitian ada 6 kelompok yaitu O1 (kontrol negatif diamati sampai hari ke-4), O2 (kontrol negatif diamati sampai hari ke-6), OK1 (kontrol positif diamati sampai hari ke-4), OK2 (kontrol positif diamati sampai hari ke-6), OP1 (kelompok perlakuan diamati sampai hari ke4), OP2 (kelompok perlakuan diamati sampai hari ke-6). Kontrol negatif adalah luka tikus tanpa diinfeksi MRSA, control positif adalah luka tikus diinfeksi MRSA, perlakuan adalah luka tikus dinfeksi MRSA dan dioles +dalethyne. Tiap kelompok berisi 6 ekor tikus (total 36 ekor tikus), tiap 6 ekor tikus diberi penomoran 1 sampai 6 dengan kertas yang lekatkan pada ekor, selanjutnya tiap tikus dirandom dimasukkan ke 6 kelompok sampai tiap kelompok terdapat 6 ekor tikus.

Setiap tikus ditimbang dan dimasukkan ke dalam kandang berukuran 20 × $15 \times 15 \mathrm{~cm}$ untuk adaptasi. Tikus di anestesi menggunakan larutan ketamin. Pembuatan larutan ketamin yaitu $3 \mathrm{ml}$ ketamin ditambah 1 $\mathrm{ml}$ xylazine diencerkan menggunakan aquabidest untuk injeksi $6 \mathrm{ml}$, lalu diinjeksi pada tikus $(0,1 \mathrm{ml}$ per tikus) hingga tikus sudah dalam keadaan tenang dan hanya terlihat pernafasan perut. Setelah tikus dalam keadaan teranestesi dicukur dengan luas bidang $3 \mathrm{~cm}$ x $3 \mathrm{~cm}$, didesinfeksi dengan betadin selanjutnya dilakukan sayatan pada kulit punggung tikus dengan pisau skapel dengan panjang luka $\pm 2 \mathrm{~cm}$ dengan kedalaman sampai lapisan subkutan.

Pada kelompok kontrol positif dan kelompok perlakuan, luka pada kulit tikus diinfeksi bakteri MRSA dengan kadar 50 mikro liter dari suspensi kuman 0,5 mcFarland dengan cara dioles menggunakan micropipet pada luka. Pemberian bakteri dilakukan setelah luka berhenti pendarahan. Pemberian krim yang mengandung senyawa aktif +dalethyne pada daerah luka pada kelompok perlakuan. Aplikasi krim yang mengandung 
senyawa aktif +dalethyne menggunakan cotton bud dilakukan 2 hari setelah terjadi infeksi. Aplikasi atau pengolesan dilakukan tiap hari. Pada hari ke-4 dan ke-6 setelah perlakuan, setiap kelompok termasuk kelompok kontrol negatif dikorbankan dengan menggunakan ketamin sebagai anestesinya. Kemudian kulit dipotong dengan cakupan kulit normal 0,5-1 $\mathrm{cm}$ dari tepi luka selanjutnya dimasukkan kedalam larutan fiksasi buffer formalin 10\% selama 15-24 jam dan selanjutnya tikus yang telah mati dikubur.

Potongan jaringan kulit selanjutnya dibuat preparat dan dilakukan pengecatan HE. Setelah itu diamati dan diukur panjang epitel dengan Optilab yang dipasang pada lensa okuler mikroskop dengan pembesaran 40x.

\section{HASIL DAN PEMBAHASAN \\ 4.1 Hasil Penelitian}

Rerata dan simpangan baku (SD) panjang epitel pada kelompok kontrol negatif, kontrol positif dan perlakuan ditunjukkan pada tabel 1, menunjukkan peningkatan panjang epitel pada kelompok perlakuan baik pada hari ke-4 dan hari ke-6 dibandingkan kelompok kontrol positif.

Kelompok perlakuan dibandingkan kelompok kontrol negatif memperlihatkan tidak jauh perbedaan panjang epitelnya baik pada hari ke-4 maupun hari ke-6.

Tabel 1 Rerata dan standar deviasi panjang epitel (konversi dari $\mu \mathrm{m}$ ke $\mathrm{mm}$ ) pada kulit

tikus Wistar yang luka pada kelompok kontrol negatif, kontrol positif dan perlakuan

\begin{tabular}{cccc}
\hline Kelompok & & Hari ke-4 & Hari ke-6 \\
\hline Kontrol & Mean & 0,59 & 0,73 \\
negative & SD & 0,711505 & 0,0083666 \\
& & & \\
\hline Kontrol & Mean & 0,21333 & 0,42 \\
Positif & SD & 0,162682 & 0,301993 \\
& & & \\
\hline Perlakuan & Mean & 0,46 & 0,638333 \\
& SD & 0,194422 & 0,761326
\end{tabular}

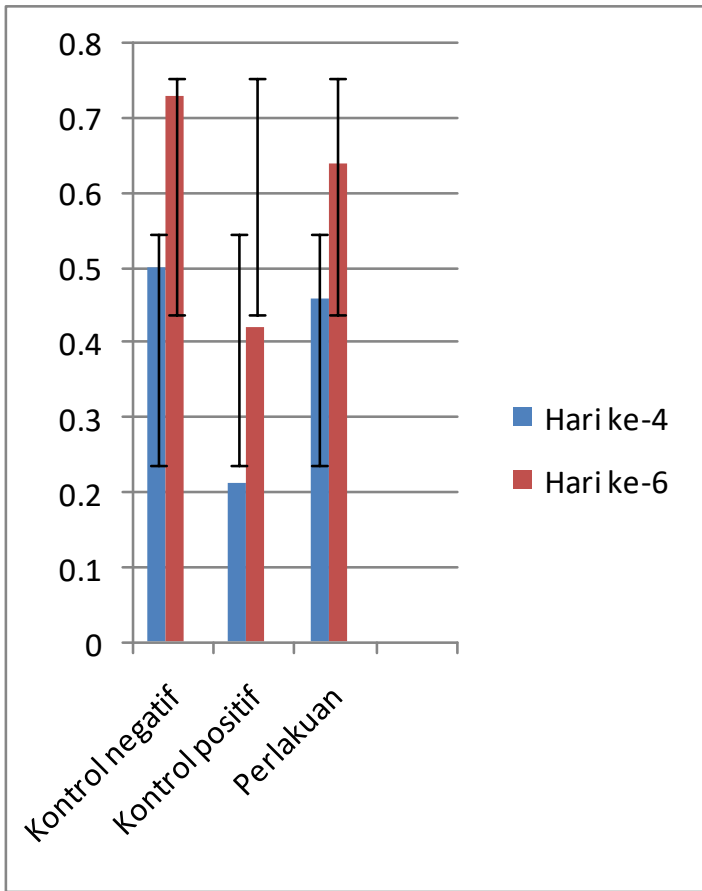

Gambar 4 Distribusi dan rerata panjang epitel masing-masing kelompok 


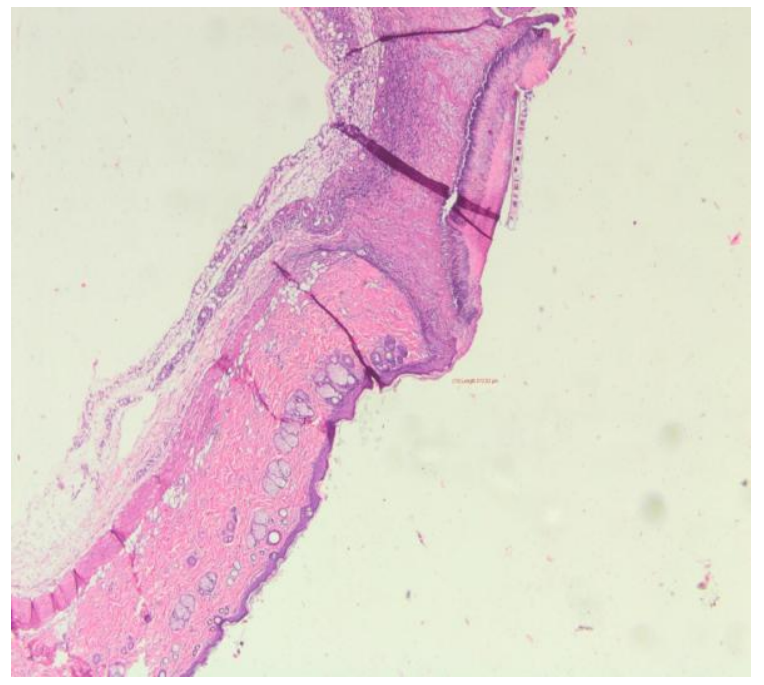

Gambar 4. Gambaran mikroskopis jaringan epitel pada hari ke-4 setelah perlukaan pada kelompok kontrol negatif (pembesaran 40x)

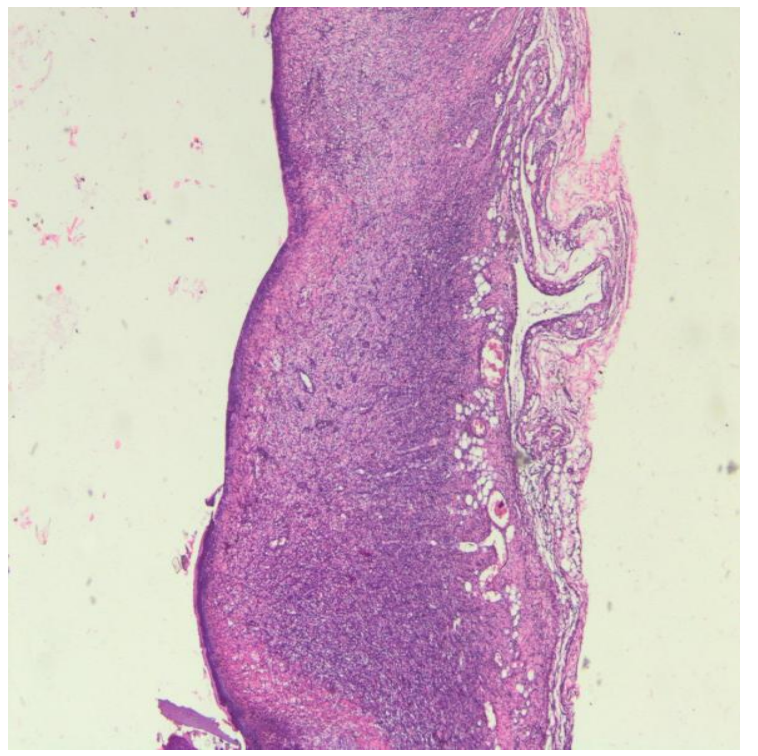

Gambar 5. Gambaran mikroskopis menunjukkan tidak adanya proses pembentukan epitel pada hari ke- 6 setelah perlukaan pada kelompok kontrol positif (pembesaran 40x)

\subsection{Pembahasan}

Pada penelitian ini, hasil rerata panjang epitel kulit tikus Wistar baik pada kontrol negatif, kontrol positif, perlakuan menunjukkan peningkatan dari hari keempat dan keenam. Hal ini menandakan adanya proses epitelisasi telah terjadi pada ketiga kelompok. Keadaan ini sesuai dengan teori proses penyembuhan luka, yaitu proses epitelisasi dimulai pada hari ke-3, lapisan epitel menutupi dasar luka. Pada kelompok control negative dan perlakuan sudah terdapat keratin, sedang pada kelompok control positif belum tampak. Pada 24 jam setelah perlukaan, keratinosit bermigrasi ke lateral dan meregenerasi membrane basalis. Setelah membrane basalis baru terbentuk, keratinosit berhenti bermigrasi selanjutnya berproliferasi sampai puncaknya pada heri ke-4.

Lapisan epitel terus memanjang dan menebal, selanjutnya jaringan epitel baru yang terbentuk mengalami pematangan dan tampak lapisan korneum baru. Dengan adanya regenerasi dari membran basalis, keratinosit kembali ke bentuk awalnya dan terjadi perlekatan kembali hemidesmosom terhadap lamina basalis. Adanya retepeg menunjukkan proses epitelisasi sedang berjalan untuk membentuk jaringan epitel yang normal kembali. Sel-sel epitel yang telah bermigrasi akan saling berhubungan dan menutup permukaan luka. Setelah mencapai ketebalan epitel yang normal, migrasi sel-sel epitel berhenti.

Pada kelompok kontrol positif menunjukkan rerata panjang epitel paling rendah. Hal ini disebabkan memanjangnya proses iuflamasi akibat infeksi MRSA. Fibroblas masih aktif membentuk komplek inflammasome menghasilkan sitokin pro inflamasi IL-1 $\beta$. Fibroblas juga berproliferasi dan berdiferensiasi mensintesis komponen jaringan granulasi (kolagen, elastin, dan proteoglikan).

Pada kelompok perlakuan, rerata panjang epitel hampir menyamai kelompok kontrol negatif. Hal ini menunjukkan +dalethyne mampu membunuh bakteri MRSA dan memicu epitelisasi sehingga waktu penyembuhan luka menyamai waktu penyembuhan luka secara fisiologis. Komponen asam lemak tidak jenuh, minyak esensial, iodine dan peroksidase mampu membunuh bakteri MRSA yang resisten terhadap antibiotik. Minyak esensial juga menurunkan $\mathrm{pH}$ lingkungan mikro luka yang 
memicu migrasi dan proliferasi dari keratinosit. Dengan pematangan jaringan epitel baru yang terbentuk, sel-sel epitel bermigrasi ke tepi luka lalu berproliferasi sampai saling berhubungan dan menutup luka.

\section{KESIMPULAN DAN SARAN 5.1 Kesimpulan}

Berdasarkan hasil dari penelitian ini, diperoleh kesimpulan aplikasi topical +dalethyne berpengaruh dalam mempercepat epitelisasi proses penyembuhan luka pada kulit tikus Wistar yang terinfeksi bakteri MRSA.

\subsection{Saran}

Penelitian ini diharapkan menjadi dasar untuk penelitian berikutnya dengan aplikasi kepada manusia, untuk melihat apakah +dalethyne juga efektif meningkatkan epitelisasi pada luka manusia terutama luka infeksi seperti luka gangren, luka dekubitus, sehingga +dalethyne bisa menjadi obat alternatif bagi luka infeksi oleh bakteri yang resisten berbagai antibiotik.

\section{DAFTAR PUSTAKA}

Abbas, AK. Andrew, H. and Pillai, S. 2015. Cellular and Molecular Immunology $8^{\text {th }}$ Edition. Philadelphia; WB Elsiver Company: Pp 35-168, 339-350, $493-$ 500

Aller, M.A. Arias, J.I. et al. 2011. OxygenRelated Inflammatory Wound utama Process, Phases, and Promoting, Jane E. Middleton (ed.). New York: Nova Science Publishers Inc. Pp. 25-48

Atiyeh, Bishara S. Dibo, Saad A. Hayeh, Shady N. 2009. Wound Cleansing, Topical Antiseptics and Wound Healing. International Wound Journal, Vol 6, No. 6: 420-438

Brittany, Busse. 2016. Wound Management in Urgent Care. Springer International Publishing Switzerland: 1-55

Bergsson, Gudmundur. Hilmarsson, Hilmar. Thormar, Halldor. 2011. Antibacterial, Antiviral and Antifungal Activities of Lipids in Lipids and Essential Oil as Antimicrobial Agents
(Halldor Thormar ed). USA: John Wiley \& Sons Ltd. Pp. 48-75

Badiu, Diana. Vasile, Monica. Teren, Ovidiu. 2011. Regulation of Wound Healing by Growth Factor and Cytokines in Wound Healing: Process, Phases, and Promoting, Jane E. Middleton (ed.). New York: Nova Science Publishers Inc. Pp. 73-93

Bergstresser, Paul R. 2008. Basic Science Approaches to the Pathophysiology of Skin Disease in the Skin in Klaus Wolff et al (ed.), Fitzpatrick's Dermatology in General Medicine seventh edition. USA: The McGrawHill Companies, Inc. Pp. 87-92

Berger, Timothy G. 2008. General Considerations of Bacterial Diseases in the Skin in Klaus Wolff et al (ed.), Fitzpatrick's Dermatology in General Medicine seventh edition. USA: The McGraw-Hill Companies, Inc. Pp. 1689-93

Cassat, James E. Smeltzer, Mark S. and Lee, Chia Y. 2014. Investigation of Biofilm Formation in Clinical Isolates of Staphylococcus aureus in Yinduo Ji (ed.), Methicillin-Resistant Staphylococcus aureus (MRSA) Protocol, Methods in Molecular Biology second edition. Springer Science+Business Media, LLC. Vol. 1085. Pp. 195-200

Cordeiro, J.V. Jacinto, A. 2013. The Role of Transcription-Independent Damage Signals in the Initiation of Epithelial Wound Healing. Nature Reviews: Molecular Cell Biology, Volume 14: Pp. 249-262

Choi, Jin Kyui. Jang, Ji-Hye. Jang, Won-Hee. Kim, Jaekwan. Bae, Il-Hong. Bae, Joonho. Park, Young-Ho. Kim, Beum Joon. Lim, Kyung-Min. and Park, Jin Woo. 2012. The Effect of Epidermal Growth Factor (EGF) Conjugated With Low-Molecular-Weight Protamine (LMWP) On Wound Healing of The Skin. Biomaterial Elsevier Ltd; 33(33): 8579-90. 
Carson, Christine F. Hammer, Katherine A. 2011. Chemistry and Bioactivity of Essential Oil in Lipids and Essential Oil as Antimicrobial Agents (Halldor Thormar ed). USA: John Wiley \& Sons Ltd. Pp. 204-223

Chu, David H. 2008. Development and Structure of Skin in the Skin in Klaus Wolff et al (ed.), Fitzpatricks's Dermatology in General M'emitine seventh edition. USA: The McGrawHill Companies, Inc. Pp. 57-72

Chin, G.A. Diegelmann, R.F. and Schultz, G.S. 2005. Cellular and Molecular regulation of Wound Healing. In (Falabella AF, Krisner RS, eds). Wound Healing. New York: Taylor\&Francis Group, pp.17-29

De Masi, Elen C.D.J. Campos, Antonio C. L. De Masi, Flavia D.J. Ratti, Marco A.S. Ike, Isabela S. and De Masi, Roberta D.J. 2015. The Influence of Growth Factors on Skin Wound Healing in Rats. Brazilian Journal of Otorhinolaryngology 293 (www.bjorl.org): 1-10

Di Ciccio, P. Vergara, A. Festino, A.R. Paludi, D. Zanardi, E. Ghidini, S. and Ianieri, A. 2015. Biofilm Formation by Staphylococcus aureus on Food Contact Surfaces: Relationship with Temperature and Cell Surface Hydrophobicity. Science Direct, Food Control, volume 50: 930-936

Delves, Peter J. Martin, Seamus J. Burton, Dennis R. and Roitt, Ivan M. 2011. Roitt's Essential Immunology. United Kingdom: John Wiley \& Sons Ltd. : 3-273

Djunaedi, Djoni. 2006. Jenis Bakteri dan Sensitivitas Antibiotik Pada Kasus Infeksi Nosokomial Akibat Pemasangan Kateter di RSSA Malang Dalam Periode November 2000-Maret 2001. Jurnal Kedokteran Brawijaya, Vol XXII, No. 3. Hal 97-100

Edward. Published on 2009. The Top Benefits of Ozonated Olive Oil. http://www.globalhealingcenter.com/n atural-health/ozonated-olive-oil/.
Diakses: 12 November 2016 jam 15.00 wib

Fitriyanti, Sepvi. 2015. Faktor Yang Mempengaruhi Terjadinya Phlebitis Di Rumah Sakit Bhayangkara TK II. H.S. Samsoeri Mertojoso Surabaya. Jurnal Berkala Epidemiologi, Vol. 3, No.2: 217-229

Faleiro, M.L. Miguel, M.G. 2013. Use of Essential Oils and Their Components against Multidrug-Resistant Bacteria in Fighting Multidrug Resistance With Herbal Extracts, Essential Oils and Their Components (Mahendra Rai and Kateryna Kon editor). USA: Elsevier Inc. Pp. 65-86

Flanagan, Madeleine. 2013. Wound Healing and Skin Integrity. USA: John Wiley \& Sons Ltd. Pp. 33-48

Fournier, Benedicte. Philpott, Dana J. 2005. Recognition of Staphylococcus by the Innate Immune System. Clinical Microbiology Reviews, Vol. 18, No. 3: 521-540

Gomes, F. Leite, B. Teixeira, P. and Oliveira, R. 2011. Strategies to control Staphylococcus epidermidis biofilms. Science against microbial pathogens: communicating current research and technological advances A. MendezVillas (Ed.): 843-852

Galkowska, H. Podbielska, A. Olszewski, Waldemar L. Stelmach, E. Luczak, M. Rosinski, G. and Karnafel, W. 2009. Epidemiology and Prevalence Of Methicillin-Resistant Staphylococcus aureus And Staphylococcus epidermidis In Patients With Diabetic Foot Ulcers: Focus On The Differences Between Species Isolated From Individuals With Ischemic vs Neuropathic Foot Ulcers. Elsevier Ireland Ltd: Diabetes Research And Clinical Practice 84. Pp 187-193

Gaynes, Robert. Edwards, J.R. 2005. Overview of Nosocomial Infections Caused by Gram-Negative Bacilli. Healthcare Epidemiology, Clinical Infections Diseases; 41: 848-54 
Galvan-Pena, Silvia. O’Neill, Luke A.J. 2014. Metabolic Reprogramming in Macrophage Polarization. Frontiers Media SA (www.frontiersin.org): Perspective Article, Vol. 5, article 420. Pp. 275-279. doi: 10.3389/fimmu.2014.00420

Han, Seung-Kyu. 2016. Innovations and Advances in Wound Healing second edition. USA: Springer-Verlag Berlin Heidelberg New York. Pp. 1-28

Haihua, Zhang. Weixiao, Nan. Shiyong, Wang. Tietao, Zhang. Huazhe, Si. Datao, Wang. Fuhe, Yang. and Guangyu, Li. 2016. Epidemal Growth Factor Promotes Proliferation of Dermal Papilla Cells Via Notch Signalling Pathway. Biochimie, Elsevier Ltd;127: 10-18

Hammer, Katherine A. Carson, Christine F. 2011. Antibacterial and Antifungal Activities of Essential Oils in Lipids and Essential Oil as Antimicrobial Agents ( Halldor Thormar ed). USA: John Wiley \& Sons Ltd. Pp. 256-295

Holland, Steven M. Loveless, James. and Beck, Lisa A. 2008. Regulation of the Production and Activation of Neutrophils and Eosinophils in General Medicine seventh edition. USA: The McGraw-Hill Companies, Inc. Pp. 279-288

Italiani, Paola. Boraschi, Diana. 2014. From Monocytes to M1/M2 macrophages: Phenotypical versus Functional Differentiation. Frontiers Media SA (www.frontiersin.org): Perspective Article, Vol. 5, article 514. Pp. 47-63. doi: 10.3389/fimmu.2014.00420

Ito, Teruyo. Kuwahara-Arai, Kyoko. Katayama, Yuki. Uebara, Yuki. Han, Xiao. Kondo, Yoko. and Hiramatsu, Keiichi. 2014. Staphylococcal Cassette Chromosome mec (SCCmec) Analysis of MRSA in Yinduo Ji (ed.), Methicillin-Resistant Staphylococcus aureus (MRSA) Protocol, Methods in Molecular Biology second edition. Springer Science+Business Media, LLC. Vol. 1085. Pp. 131-146
Ishii, Ken J. Akira, Shizuo. 2008. Nucleic Acid in Innate Immunity. USA: Taylor \& Francis Group. Pp. 43-55

Kumar, Vinay. Abbas, Abul K. Aster, Jon C. 2015. Robbins and Cotran Pathologic Basis of Disease Ninth Edition. Canada: Saunders, Elsevier.inc. Pp. 31-112

Koh, Timothy J. Dipietro, Luisa Ann. 2013. Inflammation and Wound Healing: The Role of The Macrophage. NIH Public Access Author Manuscript; 13: 1-14. doi: $10.1017 / \mathrm{S} 1462399411001943$

Kristmundsdottir, Thordis. Skulason, Skuli. 2011. Lipids as Active Ingredients in Pharmaceuticals, Cosmetics and Health Foods in Lipids and Essential Oil as Antimicrobial Agents (Halldor Thormar ed). USA: John Wiley \& Sons Ltd. Pp. 152-171

Kwakman, Paulus H.S. A. te. Velde, Anje. Vandenbroucke-Grauls, Christina M.J.E. et al. 2006. Treatment and Prevention of Staphylococcus epidermidis Experimental Biomaterial-Associated Infection by Bactericidal Peptide 2. American Society for Microbiology, Antimicrobial Agents and Chemotherapy: p. 3977-83. doi:10.1128/AAC.00575-06

Kusumawati, D. 2004. Bersahabat Dengan Hewan Coba. Jogjakarta:Gajah Mada University Press. Pp.5-8, 25-45, 7177, 82-112

Li Jie, Kirsner Robert S, 2005. Extracellular Matrix and Wound Healing In Falabella AF, Krisner RS (eds), Wound Healing. New York: Taylor \& Francis Group, pp.39-48

Murphy, Kenneth. 2017. Janeway's Immunobiology $9^{\text {th }}$ Edition. USA: Garland Science, Taylor \& Francis Group, LLC. Pp. 37-256, 345-398

Murray, Patrick R. Rosenthal, Ken S. and Pfaller, Michael A. 2016. Medical Microbiology $8^{\text {th }} \quad$ Edition. Philadelphia: Elsevier Inc. Pp. 34-96, 170-182 
Marta, Zapotoczna. Hannah, McCarthy. Justine K, Rudkin. James P, O'Gara. and Eoghan, O'Neill. 2015. An Essential Role for Coagulase in Staphylococcus aureus Biofilm Development Reveals New Therapeutic Possibilities for DeviceRelated Infections. The Journal of Infectious Diseases, volume 212, issue 12: 1883-1893

Mills, Charles D. Lenz, Laurel L. Ley, Klaus. 2014. Macrophages at The Fork in The Road to Health or Disease. Frontiers Media SA (www.frontiersin.org): Perspective Article, Vol. 6, article 59. Pp. 7-10. doi: 10.3389/fimmu.2014.00420

Mills, Charles D. Thomas, Anita C. Lens, Laurel L. Munder, Markus. 2014. Macrophage: SHIP of Immunity. Frontiers Media SA (www.frontiersin.org): Perspective Article, Vol. 5, article 620. Pp. 42-46. doi: 10.3389/fimmu.2014.00420

Marra, Andrea. 2014. Animal Models in Drug Development for MRSA in Yinduo Ji (ed.), Methicillin-Resistant Staphylococcus aureus (MRSA) Protocol, Methods in Molecular Biology second edition. Springer Science+Business Media, LLC. Vol. 1085. Pp. 333-344

Mogensen, Trine H. 2009. Pathogen Recognition and Inflamatory Signalling in Innate Immune Defenses. Clinical Microbiology Reviews, Vol. 22, No.2: 240-273

Modlin, Robert L. Kim, Jenny. Maurer, Dieter. Bangert, Christine. and Stingl, Georg. 2008. Innate and Adaptive Immunity in the Skin in Klaus Wolff et al (ed.), Fitzpatrick's Dermatology in General Medicine seventh edition. USA: The McGraw-Hill Companies, Inc. Pp. 95114

McGrath, John A. McLean, W.H. and Irwin. 2008. Genetics in Relation to the Skin in the Skin in Klaus Wolff et al (ed.), Fitzpatrick's Dermatology in General Medicine seventh edition. USA: The
McGraw-Hill Companies, Inc. Pp. 7386

Miller, Stanley J. Sun, Tung-Tien. and Coulombe, Pierre A. 2008. Epidermal Growth and Differentiation in Klaus Wolff et al (ed.), Fitzpatrick's Dermatology in General Medicine seventh edition. USA: The McGrawHill Companies, Inc. Pp. 375-382

Michalik, Liliane. Wahli, Walter. 2006. Involvement of PPAR Nuclear Receptors in Tissue Injury and Wound Repair. The Journal of Clinical Investigation (http://www.jci.org), volume 116, number 3: 598-606

Nan, Wang. Hongwei, Liang. and Ke, Zen. 2014. Molecular Mechanism that Influence the Macrophage M1-M2 Polarization Balance. Frontiers Media SA (www.frontiersin.org): Perspective Article, Vol. 5, article 614. Pp. 230236. doi: 10.3389/fimmu.2014.00420

Nugraheni, Ratna. Suhartono. Winarni, S. 2012. Infeksi Nosokomial di RSUD Setjonegoro Kabupaten Wonosobo. Media Kesehatan Masyarakat Indonesia, Vol 11 / No.1. Hal: 95-100

Nabavian, Reza. Garner, Warren L. 2002. Normal Wound Healing. LAC/USC Burn Center: 1-19

Orstead, H.L. Keast, David. Lalande, L.F. and Francoise, Marie. 2011. Basic Principles of wound healing. Wound care Canada, 9 (2): 4-12

Otto, Michael. 2009. Staphylococcus epidermidis - The "Accidental" Pathogen. NIH Public Access Author Manuscript; 7(8): 555-567. doi:10.1038/nrmicro2182

Portou, M.J. Baker, D. Abraham, D. and Tsui, J. 2015. The Innate Immune System, Toll-Like Receptors and Dermal Wound Healing: A Review. Vascular Pharmacology (www.elsevier.com/locate/vph): 31-36

Palavecino, Elizabeth L. 2014. Clinical, Epidemiologic, and Laboratory Aspect of Methicillin-Resistant Staphylococus aureus Infections in Yinduo Ji (ed.), Methicillin-Resistant Staphylococcus 
aureus (MRSA) Protocol, Methods in Molecular Biology second edition. Springer Science+Business Media, LLC. Vol. 1085. Pp. 1-19

Proksch, Ehrhardi. Jensen, Jens-Michael. 2008. Skin as an Organ of Protection in Klaus Wolff et al (ed.), Fitzpatrick's Dermatology in General Medicine seventh edition. USA: The McGrawHill Companies, Inc. Pp. 383-394

Petzelbauer, Peter. Peng, Lisan S. and Pober, Jordan S. 2008. Endothelium in Inflammation and Angiogenesis in Klaus Wolff et al (ed.), Fitzpatrick's Dermatology in General Medicine seventh edition. USA: The McGrawHill Companies, Inc. Pp. 1585-97

O'Gara, James P. Humphreys, Hillary. 2001. Staphylococcus epidermidis Biofilms: Importance and Implications. J. Med Microbiol, Vol. 50: 582-587

Rath, Meera. Mulle, Ingrid. Kropf, Pascale. Closs, Ellen I. and Munder, Markus. 2014. Metabolism via Arginase or Nitric Oxide Synthase; Two Compating Arginine Pathways in Macrophages. Frontiers Media SA (www.frontiersin.org): Perspective Article, Vol. 5, article 532. Pp. 13-19. doi: 10.3389/fimmu.2014.00420

Reddy, G.A.K. Priyanka, B. Saranya, Ch.S. and Kumar, C.K.A. 2012. Wound Healing Potential Of Indian Medicinal Plants. International Journal of Pharmacy Review \& Research. Vol: 2. pp. 58-75

Ranzato, Elia. Burlando, Bruno. 2011. Signalling Pathways in Wound Repair in Wound Healing: Process, Phases, and Promoting, Jane E. Middleton (ed.). New York: Nova Science Publishers Inc. Pp. 123-135

Rodero, Mathieu P. Khosrotehrani, Kiarash. 2010. Review Article: Skin Wound Healing Modulation by Macrophages. Int $J$ Clin Exp Pathol (www.ijcep.com); 3(7): 643-653

Rupp, Mark E. Fey, Paul D. Heilmann, C. and Gotz, F. 2001. Characterization of the Importance of Staphylococcus epidermidis Autolysin and Polysaccharide Intercellular Adhesin in the Pathogenesis of Intravascular Catheter-Associated Infection in a Rat Model. The Journal of Infections Diseases; 183: 1038-42

Sirokmany, G. Pato, Anna. Zana, Melinda. Donko, Agnes. Biro, Adrienn. Nagy, Peter. and Geiszt, Miklos. 2016. Epidermal Growth Factor (EGF)Induced Hydrogen Peroxide Production is Mediated by Dual Oxidase I. Free Radical Biology and Medicine 97 (www.elsevier.com/locate/freeradbiom ed): 204-211

Sunhyo, Ryu. Peter I, Song. Chang Ho, Seo. Hyeonsook, Cheong. and Yoonkyung, Park. 2014. Review Colonization and Infection of the Skin by Staphylococcus aureus: Immune System Evasion and the Response to Cationic Antimicrobial Peptides. Int. J. Mol. Sci, 15: 8753-8772. doi: 10.3390/ijms15058753

Sowash, Madeleine G. Uhlemann, AnneCatrin. 2014. Community-Associated Meticillin-Resistant Staphylococcus aureus Case Studies in Yinduo Ji (ed.), Methicillin-Resistant Staphylococcus aureus (MRSA) Protocol, Methods in Molecular Biology second edition. Springer Science+Business Media, LLC. Vol. 1085. Pp. 25-60

Salgado-Pabon, Wilmara. Case-Cook, Laura C. and Schlievert, Patrick M. 2014. Molecular Analysis of Staphylococcal Superantigens in Yinduo Ji (ed.), Methicillin-Resistant Staphylococcus aureus (MRSA) Protocol, Methods in Molecular Biology second edition. Springer Science+Business Media, LLC. Vol. 1085. Pp. 169-193

Soepribadi, I. 2013. Regenerasi dan Penyembuhan. Jakarta: Penerbit CV. Sagung Seto. Hal. 62-67

Scemons, D. Elston, D. 2009. Nurse to Nurse Wound Care. USA: The McGraw-Hill Companies Inc. 21-55 
Sudiana, I.K. 2006. Teknologi ilmu jaringan dan Imunohistokimia. Jakarta: Penerbit CV. Sagung Seto. Hal: 1-49

Tortora, G. J. Funke, B. R. and Case, C. L. 2016. Microbiology An Introduction $12^{\text {th }}$ Edition. USA: Pearson Education Inc. Pp. 1-5, 73-91, 442-463, 579-583

Tisserand, Robert. Young, Rodney. 2014. Essential Oil Safety: a Guide for Health Care Professionals second edition. UK: Churchill Livingstone Elsevier. Pp. 5-90

Turgeon, Mary Louise. 2014. Immunology and Serology in Laboratory Medicine Fifth Edition . Missouri: Elsevier Mosby Inc. Pp. 30-99, 197-200

Tang, Ling. Kirsner, Robert S. and Li, Jie. 2011. Extracellular Matrix Molecules in Skin Wound Repair in in Wound Healing: Process, Phases, and Promoting, Jane E. Middleton (ed.). New York: Nova Science Publishers Inc. Pp. 49-71.2010.01.022

Thormar, Halldor. 2011. Antimicrobial Lipids and Innate Immunity in Lipids and Essential Oil as Antimicrobial Agents (Thormar Halldor ed). USA: John Wiley \& Sons Ltd. Pp. 124-144

Takeuchi, Osamu. Akira, Shizuo. 2010. Pattern Recognition Receptors and Inflamation. Elsevier inc: Cell 140: 805-820. DOI 10.1016/j.cell

Travers, Jeffrey B. Mousdicas, Nico. 2008. Gram-Positive Infections Associated with Toxin Production in Klaus Wolff et al (ed.), Fitzpatrick's Dermatology in General Medicine seventh edition. USA: The McGraw-Hill Companies, Inc. Pp. 1710-19

Traversa, B. Sussman, G. 2001. The Role of Growth Factors, Cytokines and Proteases in Wound Management. Primary Intention, Vol. 9, No. 4: 161167

Yang, Junshu. Ji, Yinduo. 2014. Investigation of Staphylococcus aureus Adhesion and Invasion of Host Cells in Yinduo Ji (ed.), Methicillin-Resistant Staphylococcus aureus (MRSA) Protocol, Methods in Molecular
Biology second edition. Springer Science+Business Media, LLC. Vol. 1085. Pp. 187- 192

Zhihong, Yang. Xiu-Fen, Ming. 2014. Functions of Arginase Isoforms in Macrophage Inflamatory Responses: Impact on Cardiovascular Diseases and Metabolic Disorders. Frontiers Media SA (www.frontiersin.org): Perspective Article, Vol. 5, article 633. Pp. 178-184. doi: 10.3389/fimmu.2014.00420 